\title{
Examining the Convergences between Marx and Sen on Freedom and Institutions: Some Interpretive Notes and Issues
}

\author{
EDA LOU I. OCHANGCO \\ Far Eastern University \\ Recto Ave, 395, Manila, 1008 Metro Manila, Philippines \\ eochangco@feu.edu.ph
}

Published online: 15 October 2016

To cite this article: Ochangco, E. L. 2016. Examining the convergences between Marx and Sen on freedom and institutions: Some interpretive notes and issues. KEMANUSIAAN the Asian Journal of Humanities 23(2): 35-50, http://dx.doi.org/10.21315/kajh2016.23.2.3

To link to this article: http://dx.doi.org/10.21315/kajh2016.23.2.3

\begin{abstract}
This paper examines points of convergences between Karl Marx and Amartya Sen's conception of freedom. It begins by providing a brief interpretation of Karl Marx's ideas on freedom, and brings in some of these interpretations as complementary perspectives to Sen's conception of freedom. While it can be said that Marx did not intentionally develop systematic ideas on freedom and rights, it is however arguable that Marx himself had a very strong position on these issues, and that his ideas and perspectives may be used to further enlighten critical reflections on Sen's suggestions. One goal of this undertaking is to raise some theoretical ideas in the conceptualisation of solidarity specifically couched in Marx and Sen's language of freedom and rights.
\end{abstract}

Keywords and phrases: functionings and capabilities, positive freedom, agency, rights, Karl Marx

\section{Introduction}

One way of understanding solidarity could be in terms of freedom and rights. Such an understanding may help provide theoretical tools which could be useful in the evaluation of political institutions, social policy and individual agency which, in turn, may increase opportunities for more meaningful relations among men and women, or in other words, more opportunities for solidarity. Mutual support among equals within societies (and even within a global community) could possibly take place more easily under conditions where institutions and social policy facilitate more freedoms and rights which then may strengthen individual agency. Persons who are empowered by certain rights and freedoms and could participate as active agents in the world are, arguably, in a better 
position to be in solidarity with the rest of mankind compared to those who are disenfranchised, poor and oppressed, or colonised citizens of hegemonic Western globalisation. It is in this vein of reasoning that examining Marx and Sen's convergences on the discourses on freedom and institutions may be useful because, perhaps, as the effects of globalisation intensify (for better or worse), increasingly we realise a need not only for workers in a capitalist society but all of mankind to unite, generally. On the one hand, appreciating the more contemporary ideas of Sen on freedom, which was mainly in terms of capabilities and functionings, may already provide some useful notes for conceptualising solidarity. On the other hand, introducing and integrating the ideas of Sen on freedom with a rereading of some classic Marxian ideas may also prove to be fruitful not only for revolutionary "vocabularies" which undeniably expanded our consciousness of life and helped us deal with social realities (Brunkhorst 2007) but also for providing fresh but forceful insights needed for defining solidarity at present.

\section{Some Interpretations of Marx on Freedom and their Relations to Sen's Ideas}

A close and sensitive reading of Marx would provide ample support for an interpretation of freedom from his texts (see Marx 1938; 1947; 1967; 1974). In the following paragraphs, I shall be arguing that Marx has strongly expressed ideas on agency and positive freedom which can, to some extent, provide support for some of Sen's ideas on freedom.

Marx's affirmative position on freedom, involving agency and positive freedom, can be derived from his conception of "species-being." In this latter and very fundamental idea, which Marx takes as central in his discussions in his Economic and Philosophical Manuscripts of 1844, there seems to be a clear notion of freedom. The concept of a "species-being" is conceived by Marx as a "universal and free being" (1974, 327). Fundamental in the concept of a "species-being" is the idea that the nature of man's life activity is "free conscious activity" (1974, 328). Man as a "species being" must have freedom, and this freedom should be in terms of conscious activity - that man has conscious will, and his participation in social activities must partake of this human consciousness and freedom. This conscious life activity is what differentiates man from "animal life activity" (1974, 328). Arguably, words such as "free conscious activity" are clear expressions of ideas on freedom that derive from Marx's ideal conception of man.

Such ideas that relate to Marx's conception of "species-being," I would further argue, parallel and lend some support to Sen's concept of agency. The "agency aspect" of persons, as Sen suggests this be understood, puts emphasis on valuing what persons would want to happen with their lives, and the abilities they have to 
form objectives and have them realised $(1987,59)$. And, as Sen further suggests, man should be seen as agents who can (and should) influence the world through the communicative construction of social values and positive empowerment of certain freedoms. For instance, in relation to women and reproduction, Sen speaks of participation in value formation and freedom realisation (2000). The idea and ideal of "species-being" in Marx, as earlier suggested, places emphasis on free conscious activity; thus, it could be seen that what Marx articulates as the ideal of free conscious activity among "species beings" resonates deeply in Sen's construal of agency as the "freedom to choose lives that [people] have reason to value" $(2000,75)$.

Looking at the - arguably strong-parallelism between certain aspects of the conceptions of "species-being" and "agency," it becomes apparent that both Sen and Marx value a situation where man has possession of certain conditions in life that enhance his/her being a "species being" or an "agent": as in active willing or conscious participation in his/her life activities (and not one where he/she is merely forced into), and the presence of real opportunities and desirable options (functionings and capabilities). Arguably, both Marx and Sen conceive man to be worthy of a certain level of existence, and below such level, man ceases to be the species being or the free agent. For Marx, living below such level of existence forms part of man's alienated existence under capitalism (this will be further explored in the following section). Such an existence, I would suggest, involves various kinds of unfreedoms that again find expression in Sen. To emphasise this point, I shall examine the idea of alienation by relating this to Sen's concept of positive freedom.

Marx's conception of alienation, as the opposite of man's ideal existence as a "species being," expresses in some way-maybe less in a theoretically perspicuous and direct way (as with Sen), though perhaps more dramaticallythe basic importance of positive freedom. For as Marx strongly asserts his objections against alienation of man in the division of labour, he also consequently argues for the importance of certain conditions that will empower man in the face of coercive circumstances (imposed by the institutions of private property and the division of labour), and that will enable him/her to live the life of a "species being"; hence, his argument, in effect, for positive freedoms.

We can argue with Marx: There is a violation of positive freedom in the division of labour because it limits the worker into a way of life where he/she is compelled to produce, and to work, because otherwise, he will die. "Estranged labour turns his species-life into a means for his individual life" $(1974,328)$ and "makes man's species-life a means for his physical existence" $(1974,329)$. The lack of freedom is evident in the worker who is "enslaved" by a capitalist system 
that forces him to produce/work in order to live. In Marx's view, property is a dominating force over the worker: that the worker becomes a slave of his product by virtue of which the capitalist ensures his means of subsistence. Marx speaks of private property, for example, as compelling the workers to work "under the rule and yoke of another man" and in the process, turns their lives into machine-like type of enslavement $(1974,330)$. Alienation occurs because the worker is enslaved by the object of his work. Alienation, then, in some of its forms, may be interpreted as a state of unfreedom, and this may be seen in the situation of a worker who is left without a choice but to hire out his labour, in circumstances not of his own choosing, in order to live.

Moreover, the division of labour coerces man in certain spheres of activity that warps his humanity, and thus does not provide him/her the real freedom to pursue activities/lives of his/her own choice (what he has "reason to value," to use Sen's phraseology). Alienation in the division of labour can then be viewed as a violation of species freedom-as positive freedom-in that the worker is deprived, in a very real sense, of the freedom to pursue activities that would fulfil his humanity - his "species being"; for he is merely forced into an exclusive activity of production - activities that do not fulfil his "species being"-his potentiality for a true human existence. These conditions of alienation can be understood as violations of positive freedom.

The preceding interpretations of Marx's ideas as involving conceptions of freedom relate to and complement Sen's ideas on and arguments for positive freedom. Sen (who goes beyond Hayek's negative conception of freedom - the constraint-based approach) argues that freedom can and should also be conceived positively: in terms of the availability of real and substantive opportunities, out of which people are expected to be able to actually lead the lives they value (see Hayek 1978; Ibasco 2008). To briefly recall: Sen argues that freedom should be seen in terms of persons' functionings and capabilities to achieve things that they can and do value (2002). In an earlier work, he specifically emphasised that:

Functionings represent parts of the state of a person-in particular the various things that he or she manages to do or be in leading a life. The capability of a person reflects the alternative combinations of functionings the person can achieve, and from which he or she can choose one collection. The approach is based on a view of living as a combination of various 'doings' and 'beings,' with quality of life to be assessed in terms of the capability to achieve valuable functionings (Sen 1993, 31). 
Freedom, therefore, has to do with ability to lead different types of life as reflected in the person's capability set but which also "depends on a variety of factors, including personal characteristics and social arrangements" (1993, 33). Sen thereby argued that these functionings and capabilities be necessarily appreciated in the language of certain rights and instrumental freedoms (2000).

Our interpretation of Marx's affirmative position on the issue of positive freedom can be further seen with sensitive insights at various points. For example, he explores in passionate and often colourful detail in his "Economic and Philosophic Manuscripts" the different ways in which the worker is deprived and how he can be empowered positively. In this work, Marx critically notes the stark contrast between the life of a human being and the life of the "slave class of workers" (1974, 28). Marx must have had a conception of what supposedly would be the ideal life of a human being: one in which a person has options or opportunities to live not as an enslaved worker but as a human being-one who can freely choose to engage in what Marx calls "free conscious activity," and one in which he is not forced into and cannot escape from an exclusive sphere of activity, as well as become accomplished in any branch he wishes. Arguably, "positive freedom" must be one of Marx's basic underlying considerations for having spoken about the possibility "to hunt in the morning, fish in the afternoon, rear cattle in the evening, criticize after dinner" (Marx and Engels 1947, 53). (This, again, clearly resonates with Sen's idea of "different lifestyles"/lives that people have reason to value.) However, Marx observes that the worker in a capitalist society, far from being accomplished in any branch he wishes, and "far from being in a position to buy everything, must sell himself, and his humanity" in order for him to exist $(1974,287)$.

By critically pointing out the various inhuman conditions that beset the workers in capitalist systems, including their being poor and wretched, alienated and commodified, reduced to machines, etc.- - it could be argued that Marx must have had in mind "having greater freedom (including having real opportunities) to do the things one has reason to value and... to have valuable outcomes" (Sen 2000, 18). Arguably, Marx envisioned that the end to such an unfree and inhuman existence is in "...a higher phase of communist society, after the enslaving subordination of the individual to the division of labor, and therewith also the antithesis between mental and physical labor, has vanished" $(1938,11)$. Similarly, an implicit advocacy for "valuable" livings, of beings and doings, can be found in Marx when he expressed his criticisms on how he who lives from one-sided, abstract labour is doomed to be nothing more than a worker, a commodity, not a human being-i.e., a man living his species-life, who has the power or the freedom to exercise his will and consciousness in his speciesactivities (1974). He argues that "after labor has become not only a means of life but life's prime want; after the productive forces have also increased with the all- 
around development of the individual, and all the springs of co-operative wealth flow more abundantly - only then can the narrow horizon of bourgeois right be crossed in its entirety and society inscribe on its banners: From each according to his ability, to each according to his needs!" $(1938,11)$. Such passage from Marx suggests his strong concern for a certain conception of freedom - an ideal life of freedom in a society that fosters well-rounded human flourishing after the eradication of oppressive economic and cultural arrangements (in a capitalist society and even in the early phase of communist society) had been realised.

Furthermore (clearly supportive of, or at least coherent with, Sen's idea of positive freedom), Marx also speaks in explicit terms of rights and real opportunities for workers. For example, in his "Critique of the Gotha Programme" Marx speaks of the worker's right to receive the proceeds of his/her labour "according to his work" $(1938,13)$, at least in the earlier phase of what he calls a socialist society (a "bourgeois right" to be replaced by a system based on needs in a more advanced form of Communism, to which Sen agreed, admitting that "a system based on needs would seem to have a greater use for the complex idea we call humanity" (1972, 104-105). Moreover, the state (in a socialist society) should make allowance for: reserve or insurance funds against accidents, dislocations caused by natural calamities, etc.; and also for that which is intended for the common satisfaction of needs, such as schools, health services, etc. Also, funds must be provided for those who are unable to work, etc., in short, for what is included under so-called official poor relief. Such allowances, clearly, anticipate way in advance circumstances that are beyond control, prevent the worker from being reduced to ill health and abject misery in case of sickness, disability, or old age, etc. Education must also be provided for, at least up to a point. The preceding ideas, therefore, could be seen in some way as expressing complementary practical considerations (in terms of rights to social safety nets, right to health care, right to education, etc.), very much coherent with-indeed supportive of Sen's conception of positive freedom. Marx may have had in mind the importance of basic conditions (or what Sen calls as "real opportunities") to provide the workers freedom from the threat of beggary or starvation, ill health, etc.

Marx also speaks in his 1844 manuscripts of how, in the division of labour, the worker "denies himself, feels miserable and not happy, does not develop free mental and physical energy, but mortifies his flesh and ruins his mind" (1974, 326). It can be inferred from this that Marx is, in effect, pushing for the right to intellectual exercise and recreation among the workers. Arguably, intellectual exercise and recreation may be viewed as part of the many valuable functionings or capabilities that Sen speaks of. Furthermore, Marx also speaks in a way of the right/opportunity to participate in the life of the community when he speaks of how man's existence is a social existence and man is a social being whose vital 
expression and confirmation should be conceived in association with other men (1974), connected ideas which, again, resonate with Sen's idea of the importance of certain political and social freedoms (such as opportunity for open discussions, public scrutiny, electoral politics, etc.) (2000). For Marx, man as a "speciesbeing" implies that man by nature must not be estranged from others, but must in fact be related and connected to others in order to have a meaningful human life.

\section{Freedom, Its Meanings and Institutional Contexts: Some Old Fashioned Marxian Issues for Amartya Sen}

The above interpretive readings of Marx's understanding of freedom clearly cannot be separated from his critique of the division of labour and private property. Marx's arguments against the division of labour, the market system, and private property are in effect arguments against powerful yet repressive and coercive institutions that somehow strongly impede freedom, and that Marx's conception of a communist society of the future (which includes the abolition of the division of labour and private property) is, in a fundamental way, a strong advocacy of freedom. Hence, it is reasonable to suppose that various dimensions in Marx's thought that connect his understandings of freedom with various institutional contexts may in fact be fruitfully explored in a larger Marxist discourse on freedom. In this context, it shall be suggested that Marx's ideas on the division of labour, private property and Communism involve important freedom-relevant institutional considerations that Sen seems to disagree with, or, at least, somehow to have overlooked (for instance, it can be argued that Sen is, to a certain extent, quite enthusiastic of the powers of the market mechanism, quite unlike Marx). But without extensively pursuing all the issues that could relate Marx and Sen (certainly beyond the scope of this brief investigations), I shall now begin with a brief account that reiterates Marx's arguments against the division of labour and private property, followed by his account on Communism. Then I shall highlight a few critical issues where Marx's ideas - or the questions that such ideas pose or raise - might be contributive to Sen's attempt to build a framework for evaluation, specifically with respect to the realisation of appropriate institutional values, such as that of freedom.

As has been indicated earlier, Marx in very passionate terms criticises the division of labour and private property, particularly in connection to how they diminish (rather than contribute to) freedoms. Against the system of the division of labour and private property, Marx is, I believe, strongly expressing his stand on freedom: that, in fact, under these systems/institutions, there is no freedom, but only enslavement, as well as mental and physical degradation for the workers. The division of labour reduces man into a machine. Marx's trenchant protestations against the division of labour and capitalist private property, which 
require the subservience of the workers, can be interpreted to mean as expressions of his strong objections to a certain type of unfreedom. Marx had come to regard very critically the division of labour and private property as something like "disguised theory of slavery" (1974, 293), clearly a freedomrelated concern.

Marx thereby insists that the only way to abolish such unfreedoms is to abolish the division of labour and private property and strongly argues for "Communism"- an argument that in turn strongly supports freedom. Marx vividly speaks of true human emancipation through his conception of Communism, as "the positive supersession of private property as human selfestrangement, and hence the true appropriation of the human essence through and for man; it is the complete restoration of man to himself as a social being, i.e., human being, a restoration which has become conscious" $(1974,348)$.

Man in a Communist society - as the latter is theoretically and normatively understood by Marx - is someone who has freed himself from the domination of property and alienation from the division of labour. Arguably, through his idea of Communism, Marx could be interpreted to have conceived freedom as a form of life where man does not become powerless in the face of a certain restrictive form of existence - imposed by private property and the division of labour-and where the worker does not become merely subservient to the oppressive and inhuman labour process and does not lose his humanity in what Marx refers to, in many places, as "alienation." Marx in his work "The Poverty of Philosophy" reiterates a critique of the division of labour - "that cramping of the faculties, that narrowing of the mind, that stunting of the frame" $(1955,95)$ - that is reminiscent of Adam Smith's own contentions against the matter, where the "...great body of people, comes to be confined to a very few simply operations... [thereby becoming] as stupid and ignorant as it is possible for a human creature to become" (as cited in Rosenberg 1965, 127). Freedom is a life emancipated from the division of labour's emphasis on the"...most irksome and spirit-wasting uniformity" $(1955,95)$ to one where labour is life's prime want, an expression of agency $(1938,11)$.

Furthermore, Marx's words can be taken to suggest that the workers' freedom is curtailed by a world that is fraught with all the degrading trappings of excessive emphasis on production and profit. Marx's advocacy of Communism can and should be seen as his conception of freedom-freedom in the sense that it conceives a state of affairs that uplifts the severely restricted workers by the labour process under capitalist system, where private property and the division of labour have become "external" powers dominating over the workers and dictating 
on them what they ought to do with their lives, instead of them deciding these for themselves.

Now, Sen clearly recognises that what institutions are in place, and how they function, are important; he writes:

Our opportunities and prospects depend crucially on what institutions exist and how they function. Not only do institutions contribute to our freedoms, their roles can be sensibly evaluated in the light of their contributions to our freedom $(2000,142)$.

Elsewhere, Sen admits that "a person's ability to achieve various valuable functionings may be greatly enhanced by public action and policy... there is a very real sense in which the freedom to live the way one would like is greatly enhanced by public policy..." $(1993,44)$. In view of such, Marx's ideas in effect raise some very hard questions (for Sen and, of course, for economic, social, and political philosophy in general): what sorts of, or which, institutions could contribute to which freedoms that may be considered valuable? And in what way(s) do these contribute to these freedoms? One critical point related to policy and institutions for instance was what Sen discussed in connection to the issue of poverty (surely a very important functioning in its own right). Here Sen raised the important role of public policy in determining important measurement standards related to the evaluation and identification of poverty and inequality (Sen 1981). He took pains to emphasise that not becoming critical of traditional measurement standards (and their arbitrariness) will do little justice in the pursuit of a life relatively free from deprivation. For instance, making the important distinction between distributive from aggregative consequences, how do we assess, then, on these two different (though related) considerations, which policy measures effectively and in a morally desirable way contribute to human freedom? Related to these thus is the question: which freedoms and whose freedoms matter? For instance, should freedom from poverty take precedence over freedom from discrimination, freedom from oppression? Moreover, should the freedom of women or children supersede the freedoms of men, the freedom of the longoppressed over the recently condemned?

These are difficult questions which I cannot, at this stage, pretend to answer myself. But in relation to all the above concerns, it can be argued, at this point, that Sen's conception of freedom and its possible realisation might well be enriched by paying attention to some of the issues raised by Marx's framework of thought, especially in connection with issues that relate to freedom and relevant institutions; how institutions - such as, for instance, the division of labour and 
private property - promote or hamper human freedoms. With Sen's justified concern with the plurality and interconnections of freedom, it might also be necessary for him to consider the interconnections and consequences of freedoms for various arrangements/institutions, including (if necessary) some conception of property, of the division of labour, of the market, and so on. Sen seems to have assumed that these institutions - which Marx vehemently attacked — can, in large measure, be taken for granted as contributing to freedoms. I do not think however that it is obvious that this is the case. But clearly, these are not easy questions to address; but I believe they need to be confronted.

\section{Some Issues and Difficulties: Sen's Freedom vs. Marx's "Human Emancipation"}

Interpreting Marx, it should be emphasised, can be quite a complex undertaking fraught with problems. The complexity of his ideas (and possible contradictions within) can give rise to difficult hermeneutical issues and lend them different interpretations. For instance, Marx's ideas in his work "On the Jewish Question" seems to express very strong reservations to conceptions of "political freedom" or what he calls "political emancipation," reservations which make an account of freedom (particularly positive freedom) in his name in some respects philosophically problematic (1967). An interpretation of his conception of positive freedom (as discussed above) in terms of rights and liberties would seem, within this context, questionable and would appear contradictory to (at least some of) Sen's account, contrary to our earlier reading.

Marx speaks of how, in the context of political emancipation, certain rights to equality, liberty, security and property actually limit man's freedom, instead of being a realisation of freedom. He argues that the political rights that come with political emancipation are rights of the "egoistic man" who is separated from other men and from the community; liberty is "a right of man [that] is not based on the association of man with man but rather on the separation from man" (1967, 235). For Marx, "political emancipation" is not "complete" "human emancipation" and that, in fact, political emancipation is a reduction of man to an egoistic individual $(1967,241)$.

For instance, in the right of private property (as an application of right of liberty), Marx explains that such a right is nothing but the right of self-interest because it is but "the right to enjoy and dispose of one's possession as one wills, without regard for other men and independently of society" and the right "to enjoy and dispose of his goods, his revenues, the fruits of his labor and of his industry as he wills" $(1967,236)$. Hence, the right to private property, as one exercise of the right of liberty, "lets every man find in other men not the realization but rather 
the limitation of his own freedom" $(1967,236)$. On the right to security, Marx argues that it is but "the guarantee of egoism," where security is defined as "the protection accorded to society to each of its members for the preservation of his person, his rights and his property" $(1967,236)$. Marx is critical of how such right further supports the man who is, as he puts it, simply "withdrawn into himself and his private choice, separated from the community as a member of civil society" $(1967,237)$.

Hence, instead of political emancipation (together with its right to liberty, property, equality, and security), Marx speaks of some form of "human emancipation" as a desirable ideal, to be realised in his ideal of a communist or co-operative society of the future. In such social arrangement, one can draw the inference that since Marx conceives of a situation where the means of production and the proceeds of labour are already for common-ownership (1938, 14-15), rights (in the way they are defined above) are no longer necessary and hence have to be abandoned. This would be so since Marx conceives of the ideal communal life as one where men are not separated by their selfish interests but rather, are actually united together by virtue of mutual interdependence among them and where, instead of individual interests, communal interests reign. Since everything is already communally owned (and where the "springs of co-operative wealth flow more abundantly"), rights that protect property and assign what to whom seem no longer necessary. One can understand how Marx could, with his idea of communism and of the real human emancipation he seems to associate with it, eventually abandon the concept of rights - even attack its historical conceptual and social limitations - something he seems to have initially used and presupposed in light of his critical concerns on the plight of workers in a capitalist system. Certainly of course, such conceptual and hermeneutical issues can perhaps be clarified by understanding the different contexts within which Marx and Sen can be seen to situate their conceptions of freedoms. Sen, especially in his book "Development as Freedom," speaks of the importance of freedom, characterised by capabilities, rights, and instrumental freedoms, in a context of poverty, scarcity, and widespread deprivation; hence, there is the most pressing need to "empower" people through certain freedoms, rights and capabilities in order to survive, and live as "human beings" (2000). By contrast, Marx speaks of the limitations of the concepts of rights in a context where "all the springs of co-operative wealth flow more abundantly" $(1938,17)$, where men, as "species-beings," share and enjoy communal interests (and therefore, not in a state of scarcity).

Thus far, looking closer at such considerations, it might also be argued that while Marx's ideal communal society appears to be desirable (and to some extent, to even enlighten Sen's own approach to freedom, as argued above), perhaps it cannot totally do away with rights and other liberties, as Marx himself seems to 
argue in "On The Jewish Question." The reality of our times reflects a situation that Sen describes as a time of utter scarcity and deprivation, hence, the need to recognise the important use of the complementary concepts of rights/capabilities/liberties. These concepts still have, I believe, very important works to do. While Marx's description of the wealthy communal society maybe enchanting, the world today still has much to learn from Sen' strong and passionate advocacy of certain rights and capabilities. More than half of the world is trapped in the quagmire of poverty and destitution; it is faced with the urgency of addressing issues that are matters of life and death. In this case, conceptualising rights and capabilities and their appropriate institutionalisation, I believe, may prove to be crucial for the betterment of men's condition, and not one where we do away with it. In the context of scarcity or poor developing economies, using the language of rights and capabilities may still prove to be important in providing answers to serious matters of just distribution and the right allocation of resources. Wealth and stability in a society can be attainable and sustainable only in a situation where human beings are continually empowered by certain rights and liberties. Rights, together with capabilities or real opportunities, in the language of Sen, are like the oil that starts and keeps the engine of life running, so to speak, and without these, no genuine human activity is ever possible in societies marked by some degree of pluralism (see also Nussbaum 1999; Ochangco 2009).

Moreover, conflict of interest, which may not necessarily be in terms of material considerations, may still be a central problem in the hypothetical communal society where wealth is already flowing abundantly. For instance, people, who have different conceptions of the good - a real possibility one always has to consider-would still need "rights" to protect them from those others who, without the virtue of tolerance, might want to impose their own conceptions of the good. Wealth and abundance do not necessarily presuppose a monist conception of the good. Hence, people would still have the need for rights to pursue activities and lifestyles of their own choice. Rights in such manner may indeed, to some extent, be perceived as "egoistical" as Marx fears of certain rights. But such rights may be practically necessary to respect man's choices and decisions, and ultimately, to respect man's dignity in choosing, for instance, to live the life he has reason to value. 


\section{Concluding Reflections}

As concluding remarks, I further put forward the following related considerations that somehow suggest other aspects that may further enrich our conceptualisation of freedom and their appropriate institutional contexts:

a) In a communal society, Marx has expressed emphasis on man's freedom to exist as a thinking being, to appropriate one's integral essence in an integral way, as a total man $(1974,351)$. The idea of a thinking being somehow resonates with Sen's idea of valuations. But Marx's idea of a thinking being presupposes the presence of what might be called "species-beingconsciousness" and the institutional conditions for their flourishing, and therefore, also the absence of enslaving and alienating institutions that threaten such consciousness from without. Such ideas are important because they define freedom in a larger institutional context of choice and valuation-freedom in the sense that one is conscious that one's valuations and rationality are not threatened and warped by institutional conditions (such as, for Marx, private property and the division of labour). Freedom here means that the total integral man is able to express and develop himself fully, aware that he/she is not threatened by certain historically limiting institutional conditions; that $\mathrm{s} / \mathrm{he}$ can be a total and integral human being, and choose to be accomplished in any branch he/she wishes by virtue of the absence of certain institutions that limits him/her into an exclusive sphere of activity, and the presence of enabling institutions that provide genuine choice of life. In more limited real world contexts that are less than ideal, institutions that would ensure rights and capabilities that relate to education and information, leisure and other opportunities and conditions for human development are particularly relevant here.

b) In the context of Communism, the idea of man as a social being (in real association with other men) puts emphasis on a certain type of freedom: a type of freedom that is expressive of human essence- where man's "existence for others and their existence for him [is] the vital element of human reality" and species-consciousness - "the affirmation of himself/herself as a social being" (1974, 349-350). Such type of freedom, though quite similar to Sen's idea of political and social freedoms (e.g., freedom to participate in political discussions and in the life of the community, freedom/right to vote, freedom of the press, etc.), should not be overlooked for it directs critical attention to how certain institutions possibly hamper freedom, especially if they are left unchecked or unregulated (i.e., the institution of markets/division of labour/private property/capitalism). In this respect, man must have the freedom to live with others and to be a social being, but the realisation of such freedom requires that the negative effects of 
certain institutions (in particular, the institutions that were the objects of Marx's criticisms) must not remain unexamined. The harshness of the conditions of work and the stifling character of the division of labour under capitalism, the lack of (or severely inadequate) workers' power and control within the domain of capitalist private property-these (and related concerns), following Marx, could affect human flourishing in general, and his capability for genuine human association in particular. Freedom must mean that man has to be equipped with certain political and social rights and capabilities; it must also mean the absence - or the eventual and progressive extirpation - of certain repressive/oppressive institutions that limit (if they do not totally negate) those freedoms and capabilities.

c) Through Communism, Marx seeks to abolish private property and the division of labour because they make the workers "the slave of other men who have made themselves the owners of the objective conditions of labour" $(1936,9)$; hence, the freedom to live independently and not one where existence is owed to another (1974). Without necessarily advocating Communism (as this was theoretically and normatively understood), I believe that there is wisdom in the words of Marx when he emphasised the value of such independence in various ways. Here, the freedom to live independently may be taken to suggest very strongly a kind of life that has the space to live, think, feel and pursue meaningful activities outside the dominating institution of private property in the means of production and its expressions. It means the freedom to conceive of, design and create one's life in accordance with one's enlightened choices/preferences, and not where one is unduly influenced or exploited by, say the power of money, in its various expressions, under the system of private property. I believe this point is important; but unfortunately Sen's conception of freedom does not address issues that relate to this drive of property to produce, sell and make profit, with their ramifications on culture and people's lives. Arguably, Sen, through his concept of 'capabilities,' could be taken as speaking of a related concern, for the freedom to live "independently" when he argued for the importance to pursue different "lifestyles" or lives that people have reason to value (2000, 75). But this might miss what seems to be a crucial issue raised by Marx: "Under the system of private property...each person speculates on creating a new need in the other, with the aim of forcing him to make a new sacrifice, placing him in a new dependence and seducing him into a new kind of enjoyment and hence into economic ruin" $(1974,358)$. Under such system, one's freedom/independence is constantly threatened because, "Each attempts to establish over the other an alien power, in the hope of thereby achieving satisfaction of his/her own selfish needs" $(1974,358)$. Under such system, one may always be at the disposal of his neighbour's most depraved fancies, who panders to his needs, excites unhealthy appetites in him, and pounces on 
every weakness, so that that neighbour can demand money for "his labour of love" $(1974,359)$. In other words, the pursuance of Sen's valued/preferred lives/lifestyles might still be highly vulnerable to what today are the strong clutches of capitalist/consumerist culture, true to the words of Marx one and half century ago. The evils of the division of labour might not be as intense now compared to how it was during the time of Marx; however, something still remains so true today, that "...for private property... its idealism is fantasy, caprice and infatuation" $(1974,359)$. Such issues direct our attention back to certain questions about autonomy, related capabilities and their development by appropriate institutions: For instance, are our developed capabilities that have been, to some degree at least, shaped/distorted by consumerist/capitalist values desirable? Are lifestyles/"doings" and "beings" immersed in the excesses and exploits of capitalist practices to be considered worth pursuing just because they are the reflections of men's choices? What institutional mechanisms could help us with capabilities to make more genuine and independent choices? (Would the regulation of markets, for instance, those aspects related to advertising, help in this regard?)

d) Marx's conception of Communism emphasises some freedom from state coercion, as implicitly expressed here: "Freedom consists in converting the state from an organ standing above society into one completely subordinate to it" $(1938,26)$. While Marx's ("complete") communist "anarchy" might not really be a tenable idea after all, it might be useful to re-examine the role of the state in the provision of freedoms. Sen had strongly expressed his confidence on the role of governments (especially democracies) in the provisions and arrangements of different freedoms (though he places his reliance on a broader set of forces). In this connection, it is also important to consider how governments may not actually help furnish freedoms but may in fact be the very threats to freedom (even in Sen's "democracies"). Marx's ideas and perspectives on the effects of unequal social and class structures on institutional-including political-arrangements could help us re-consider and be sensitive to how governments and "democracies" (despite plural voting and freedom of expression and other rights) may, not infrequently, only serve - or predominantly serve - the interests of the more powerful or wealthier classes in the society at the expense of other marginalised and lessprivileged classes. Sen's enthusiasm for democratic system of governments might have been duly justified, especially with the presence of certain political rights and freedoms; however, such freedoms/rights might still prove to be insufficient weapons in the face of circumstances where so-called democracies are also at the mercy of giant capitalists and other powerful social and economic interests. These considerations seem to suggest that distributive issues of power, freedom and capability - towards a more egalitarian state of affairs - need to be addressed adequately, as opposed to 
merely efficiency and aggregative issues, even when couched in the "metric" of freedom. Institutional mechanisms towards such a more egalitarian distribution of power and capabilities need to be addressed in tandem.

\section{References}

Brunkhorst, H. 2007. Globalizing solidarity: The destiny of democratic solidarity in the times of global capitalism, global religion, and the global public. Journal of Social Philosophy 38(1): 93-111.

Hayek, F. V. 1978. The Constitution of liberty. Chicago: University of Chicago Press.

Ibasco, E. L. 2008. Amartya Sen's plural conception of freedom (its impact on institutions, policy and individual agency. Department of Humanities and Social Sciences Research Journal, Far Eastern University Colloquium 2, 123-144.

Marx, K. 1844/1974. The economic and philosophical manuscripts of 1844. Harmondsworth: Penguin. . 1847/1955. The poverty of philosophy. Paris: Progress Publishers. . 1875/1938. Critique of the Gotha programme, English translation. New York: International Publishers. . 1967. On the Jewish question. Reprinted in Writings of the young Marx in philosophy and society, eds. Easton, L. D. and Guddat, K., 216-248. New York: Doubleday.

Marx, K. and Engels, F. (1845-1846/1947). The German ideology, English translation. New York: International Publishers.

Nussbaum, M. 1999. Women and human development: The capabilities approach. Cambridge: Cambridge University Press.

Ochangco, E. L. I. 2009. On human development and freedom: Critical considerations on Nussbaum's contributions to the capabilities approach. Department of Humanities and Social Sciences Research Journal, Far Eastern University Colloquium 3, 157-177.

Rosenberg, N. 1965. Adam Smith on the division of labour: Two views or one? Economica 32(126): 127-139.

Sen, A. K. 1972. On economic equality. Oxford: Clarendon Press. 1981. Poverty and famines: An essay on entitlement and deprivation. Oxford: Oxford University Press. . 1987. On ethics and economics. Oxford: Blackwell. . 1993. Capability and well-being. In The quality of life, eds. Nussbaum, M. and Sen, A. K., 30-53. Oxford: Oxford University Press. 2000. Development as freedom. New York: Random House. 2002. Rationality and freedom. Harvard: Harvard University Press. 